\title{
GERAKAN SALAFI DAN DERADIKALISASI ISLAM DI INDONESIA
}

\author{
Slamet Muliono \\ UIN Sunan Ampel Surabaya \\ smuliono@gmail.com
}

\author{
Andi Suwarko \\ UIN Sunan Ampel Surabaya \\ Andisuwarko@uinsby.ac.id \\ Zaky Ismail \\ UIN Sunan Ampel Surabaya \\ zakyismail@uinsby.ac.id
}

\begin{abstract}
The Salafi (Wahabi) movement in Indonesia in recent decades is growing rapidly. Generally, the group is often considered as part of takfiriy, radical or terrorist group considering its similarity in rejecting the heresy (bidab) practices and its view on democracy. This research attempts to explore how its religious teaching and strategies as well as its compatibility to deradicalization efforts. The research uses Hertbert Blumer's theory which classifies the development of a movement in four stages; social chaos, popular excitement, formalization and institutionalization. This research found that their Islamic teaching merely refers to the model of Islam practiced by three early generations. Meanwhile, the strategy undertaken is focused on teaching tauhid through education that has been purified (tasfiyah) and tarbiyah. Compatibility to deradicalization of this group lies on the evidence that Salafi is different with takfiriy, radical or terrorist group. Moreover, they believe that Pancasila is not against Islam.
\end{abstract}


[Artikel ini mendeskripsikan kompatibilitas gerakan Salafi dengan deradikalisasi Islam di Indonesia. Fenomena maraknya gerakangerakan radikal sehingga melahirkan aksi terorisme dan membesarnya gerakan Salafi merupakan sebuah kebetulan. Dikatakan kebetulan karena gerakan Salafi dikaitkan dengan gerakan radikalisme dan terorisme. Pada saat yang sama gerakan Salafi menolak dirinya dikaitkan dengan gerakan radikal dan terorisme dan menyatakan diri sebagai gerakan dakwah yang memerangi aksi radikalisme dan terorisme. Dalam dakwahnya, kaum Salafi mengklaim diri melawan gerakan-gerakan yang tidak ada dalam ajaran Islam, sehingga sangat relevan jika gerakan Salafi sangat kompatibel dengan gerakan deradikalisasi Islam di Indonesia.]

Keywords: compatibility, salafi movement, deradicalization.

\section{Pendahuluan}

Perkembangan gerakan Salafi yang begitu masif dan munculnya penolakan sebagian anggota masyarakat terhadap gerakan tersebut merupakan fenomena yang unik dan menarik dicermati. Dalam menyikapi fenomena tersebut masyarakat tidak satu suara. Sebagain kelompok menerima untuk membela eksistensinya, sedangkan sebagian yang lain dengan tegas menolak dengan berbagai alasan.

Demonstrasi untuk menghentikan pembangunan Masjid Imam Ahmad bin Hanbal (MIAH), Bogor, atau tuntutan menghentikan dakwah dan penolakan pembangunan masjid di Gresik, atau penyegelan masjid di Pekalongan dengan alasan tidak mempunyai izin pendirian bangunan (IMB), merupakan sebagian contoh fenomena penolakan terhadap gerakan Salafi. Bahkan, pembubaran pengajian dan penolakan terhadap ustad-ustad yang dianggap sebagai dai beraliran Salafi juga muncul di beberapa tempat di wilayah Sidoarjo, Jawa Timur. Reaksi negatif ini tidak lepas dari stigma Salafi-Wahabi yang dianggap sebagai paham keagamaan yang membahayakan ideologi negara dan mengancam budaya masyarakat lokal. ${ }^{1}$

${ }^{1}$ Banyak media sosial yang memuat penolakan masyarakat terhadap keberadaan gerakan Salafi yang dianggap membahayakan budaya lokal masyarakat serta membahayakan bagi negara. Muncul dan berkembangnya radio dakwah Salafi juga menjadi fenomena perkembangan dakwah Salafi yang begitu masif. Lihat buku Din 
Diskusi mengenai gerakan Salafi ini kemudian menjadi menarik berdasarkan beberapa pertimbangan semisal perkembangan gerakan Salafi yang masif di berbagai daerah dan menyentuh berbagai lapisan masyarakat, bahkan telah mampu bertransformasi menjadi sebuah gerakan berskala global. ${ }^{2}$ Pada tingkat global, perkembangan itu bisa dilihat dari pertumbuhannya gerakan Salafi di berbagai negara, baik di Eropa, Amerika, Afrika, dan Asia.

Diakui atau tidak, perkembangan dan dinamika gerakan kaum Salafi di Indonesia menjadi semakin besar dan berhasil mendapatkan simpati masyarakat. Dilihat dari sudut pandang model dakwahnya, setidaknya ada beberapa narasi besar dan menarik untuk diangkat sebagai sebuah kajian akademik. Pertama, gerakan Salafi atau gerakan dakwah tauhid telah berkembang secara masif. Gerakan ini pada kenyataannya telah mempengaruhi berbagai lini dan strata sosial. Hal ini pada perkembangannya mampu menumbuhkan kesadaran beragama yang tinggi di masyarakat.

Kedua, tumbuhnya lembaga-lembaga pendidikan beraliran Salafi. Menjamurnya lembaga-lembaga pendidikan tersebut merupakan fenomena baru dan faktanya cukup berhasil mengubah cara berpikir (mindset) masyarakat dalam melihat realitas kehidupan.

Ketiga, lahirnya lembaga-lembaga penerbitan, media sosial dan komunikasi serta audio-visual yang faktanya model dakwah melalui mediamedia tersebut telah berhasil secara masif memberikan pengaruh yang signifikan terhadap masyarakat secara lintas wilayah dan generasi.

Keempat, gerakan Salafi mengalami perlawanan kolektif. Dalam hal ini perkembangan dakwah tauhid yang begitu luas ini tidak lepas dari respons negatif dari banyak pihak. Label sebagai kelompok yang identik dengan radikalisme dan terorisme telah melekat pada gerakan Salafi yang lebih dikenal sengan sebutan "Wahabi." Labelisasi wahabi secara perlahan

Wahid dan Jamhari, Suara Salafisme Radio Dakwah di Indonesia (Jakarta: Pusat Pengkajian Islam dan Masyarakat dan PrenadaMedia Group, 2017).

${ }^{2}$ Roel Meijer, Global Salafism, Islam's New Religious Movement (London: Hurst and Company), 2009. 
turut pula membentuk sebuah opini publik yang mengasumsikan bahwa gerakan ini dipercaya berasal dari Arab Saudi. ${ }^{3}$

Respons terhadap gerakan Salafi ini juga telah menciptakan dua arus kelompok masyarakat yang berbeda. Di satu sisi ada penguatan dukungan yang begitu tinggi dari masyarakat yang bersimpati, namun di sisi lain muncul sikap ragu dan curiga yang pada akhirnya melahirkan sikap perlawanan. Respons kelompok yang terakhir ini lebih banyak muncul di permukaan yang diekspresikan dengan berbagai aksi penolakan. Kelompok ini melihat bahwa gerakan Salafi dapat membahayakan ideologi negara.

Kelompok tradisionalis, seperti Nahdhatul Ulama (NU) atau masyarakat yang teguh dalam memegang tradisi atau adat lokal, merupakan salah satu contoh kelompok yang melawan tumbuhnya gerakan Salafi. Bahkan, NU saat ini berhasil memegang bendera perlawanan terhadap gerakan Salafi ini, dengan mengibarkan pentingnya NKRI dan ideologi negara, Pancasila. Bagi NU, gerakan Salafi dianggap dianggap berbahaya karena memiliki banyak perbedaan pemahaman terhadap budaya yang berkembang di masyarakat.

Dengan demikian, gerakan Salafi, dengan label wahabi, telah menjadi musuh bersama (common enemy). Bahkan muncul sebuah pernyataan tersebar di media sosial bahwa Indonesia dalam keadaan darurat wahabi karena perkembangan gerakan Salafi yang demikian besar. Dengan munculnya pernyataan tersebut, secara otomatis gerakan Salafi dianggap sebagai gerakan yang membahayakan negara. Oleh karena itu, melawan gerakan Salafi kemudian dianggap sama dengan membela keberadaan ideologi negara dan menjaganya dari bahaya yang merongrong bangsa.

Gerakan Salafi dikenal sebagai gerakan dakwah yang sangat selektif terhadap kultur yang berkembang di masyarakat. Mereka ingin mewujudkan tatanan masyarakat yang didasarkan pada apa yang diperjuangkan oleh tiga generasi utama dalam Islam, yakni generasi sahabat dan tabiin. Perkembangan dakwah salaf yang begitu pesat, dengan dakwahnya yang semakin meluas, justru dilihat secara pesimis dan

\footnotetext{
${ }^{3}$ Zaki Mubarok, Genealogi Gerakan Radikal Islam Indonesia (Jakarta: LP3ES, 2003).
} 
dianggap kurang memperoleh tempat di Indonesia. Hal itu diungkapkan Azyumardi Azra yang begitu pesimis terhadap masa depan gerakan fundamentalis (wahabi), karena karakter yang reaksioner dan radikal terhadap realitas sosial yang dihadapinya. ${ }^{4}$

Peneliti melihat bahwa perkembangan gerakan Salafi berbeda dengan gerakan-gerakan fundamentalis yang lain karena penggunaan pola dan strategi yang berbeda sebagaimana yang dikatakan oleh Ian Adams. ${ }^{5}$ Perbedaan pola dan model gerakan tersebut di antaranya sebagai berikut. Pertama, mereka taat terhadap pemerintah dan tidak pernah melakukan kritik secara terbuka, baik melalui media massa, buletin, majalah, buku yang mereka terbitkan, atau bahkan di mimbar atau khotbah. ${ }^{6}$ Kedua, tidak memiliki organisasi layaknya organisasi pada umumnya, seperti model struktur organisasi, keanggotaan yang jelas, serta dalam mekanisme memilih pemimpin, dan laporan administrasi. Ketiga, pemahaman Islam yang benar yang hanya merujuk pada Alquran dan Sunah Nabi dengan pemahaman tiga generasi pertama: sahabat, tabiin, dan tabiin-tabiin. ${ }^{7}$ Keempat, melakukan pemurnian Islam dan melawan berbagai praktikpraktik baru dalam agama (bidah). Perbuatan bidah, bagi kelompok Salafi, dianggap telah menodai ajaran Islam, sehingga harus perlu adanya pemurnian akidah yang tercampur dengan berbagai praktik ritual yang bukan berasal dari Islam. ${ }^{8}$ Kelima, tașfiyah dan tarbiyah. Tassfiyah adalah sebuah proses pembersihan ajaran Islam, sedangkan tarbiyah adalah sebuah proses pendidikan terhadap umat dengan ajaran Islam yang telah mengalami proses tasfiyah. ${ }^{9}$ Keenam, perkembangannya yang besar bahkan

\footnotetext{
${ }^{4}$ Azyumardi Azra, Pergolakan Politik Islam: Dari Fundamantalisme, Modernisme, hingga Post-Modernisme (Jakarta: Paramadina,1999), 123.

${ }^{5}$ Ian Adams, Ideologi Politk Mutakhir (Yogyakarta: 2004), 426.

${ }^{6}$ Abdurrahman bin Thayyib, "Menepis Tuduhan, Membela Tuduhan," Majalah alDzakhirah al-Islamiyah, Edisi 15 tahun III(Rajab 1426/Agustus 2005), 19; lihat juga Abdurrahman Hadi, "Genggamlah Sunnah, Taati Penguasa," al-Dzakhirah alIslamiyah, Vol. 6 no 9 edisi 41 (1429).

${ }^{7}$ Yazid ibnu Abdul Qadir Jawwaz, Sharah 'Aqidah Ahl al-Sunnah wa al-Jama'ah (Jakarta: Pustaka Imam Asy-Syafi'i, 2006), 34.

8 Syaikh Abdullah bin Shalih 'Ubailan, "Pelajaran tentang Manhaj Salaf," alDzakhirah al-Islamiyah, edisi tahun 1 No 05(1424/2003).

9 Abdul Malik Ramadhani, Enam Pilar Dakwah Salafiyah (Jakarta: Pustaka Imam Asy-Syafi'i, 2000), 84.
} 
dalam level global dan terfragmentasi. ${ }^{10}$ Ketujuh, adanya pertemuan para penyeru (dai) Salafi secara berkala di berbagai daerah dengan mendatangkan mashayikh dari Timur Tengah. ${ }^{11}$

Berdasarkan realitas di atas, maka peneliti melihat bahwa menarik untuk menelusuri bagaimana dinamika dan perkembangan gerakan Salafi terkait dengan proyek deradikalisasi di Indonesia. Banyak stigma yang dilekatkan pada gerakan Salafi yang diidentikkan dengan radikalisme dan terorisme, tetapi di sisi lain gerakan Salafi mengaku sebagai kelompok yang memerangi radikalisme dan terorisme karena mengganggu keamanan negara.

Dalam konteks bernegara, kompatibilitas kaum Salafi dengan deradikalisasi Islam di Indonesia juga merupakan hal yang tidak kalah menarik untuk dikaji mengingat gerakan Salafi memantapkan diri sebagai gerakan dakwah yang memerangi gerakan radikalisme dan terorisme. Namun, dalam tataran empirik, gerakan Salafi justru sebagai korban adanya stigma yang melekat pada dirinya sebagai kelompok radikal yang mendukung terorisme.

Untuk memotret gerakan Salafi di berbagai tempat dan wilayah, maka akan memudahkan bagi negara untuk melakukan deradikalisasi Islam di berbagai wilayah dan sektor kehidupan, baik dalam lingkup mikro maupun makro.

\section{Problem Akademik, Pendekatan, dan Penelitian Terdahulu}

Tulisan ini akan menjelaskan secara berurutan bagaimana paham keagamaan, pola gerakan, dan kompatibilitas Salafi dengan deradikalisasi Islam di Indonesia. Dengan demikian akan tergambar kegunaan teoritis dan praktis dari penelitian ini. Kegunaan Teoritis adalah untuk menambah khazanah pengembangan teori, konsep, perspektif, isu baru tentang studi gerakan Islam trans-nasional yang berkembang di Indonesia. Di satu sisi gerakan Salafi bisa dipotret sebagai paham keagamaan yang dianggap

\footnotetext{
${ }^{10}$ Terje Ostebo, Growth and fragmentation: The Salafi Movement in Bale, Ethiopia, dalam Roel Meijer, Global Salafism, Islam's New Religious Movement (London: Hurst and Company), 2009), 354-361.

${ }^{11}$ Para dai kaum Salafi setahun sekali mengadakan pertemuan untuk melakukan pelatihan (daurah) yang dihadiri para shaikh dari Timur Tengah.
} 
sebagai bagian dari kelompok radikal, dan di sisi lain bisa dilihat sebagai gerakan yang melakukan deradikalisasi Islam.

Adapun kegunaan praktisnya, gerakan Salafi bisa dijadikan sebagai bahan rujukan, refleksi, dan proyeksi bagi aktivis/fungsionaris gerakan Islam, pemerintah, kalangan penguasa dalam memahami paham keagamaan dan pola gerakan Salafi di Indonesia, serta dalam merumuskan maupun menerapkan strategi deradikalisasi Islam di Indonesia.

Ada beberapa penelitian terdahulu yang penting sebagai pijakan dan perbandingan terhadap penelitian ini. Pertama, artikel yang ditulis oleh Frazer Egerton "Alienation and its discontent." Tulisan ini membahas bagaimana terorisme menjadi fenomena yang sering dibahas namun seringkali kurang dipahami. Terdapat banyak literatur yang terus dikembangkan tentang Salafisme militan di Barat. Sebagian besar tulisantulisan tersebut mengemukakan bahwa ada semacam keterasingan sebagai penjelasan mengapa jalan militansi ditempuh. Artikel ini juga membahas tentang keterasingan nilai penjelas yang dirasakan untuk menawarkan tindakan semacam itu. Kemudian mempertimbangkan beberapa masalah besar yang dihadapi klaim ini, kesulitan yang secara serius melemahkan kegunaan alienasi sebagai konsep yang membantu kita memahami militansi.

Kedua, artikel "Radicalisation and De-Radicalisation of Social Movement: The Comeback of Political Islam" yang ditulis oleh Andreas Amborst. artikel ini mengambil pelajaran penting dari political of abolition karya Mathiesen. Ia menjelaskan bahwa mekanisme dua faktor sosial yang memoderatori tujuan dan cara kelompok abolisionis yang paling diperebutkan. Berdasarkan mekanisme ini, gerakan abolisionis sering terbagi menjadi dua arus: kelompok yang moderat dan kelompok radikal. Gerakan Islam adalah contoh konkret untuk perpecahan yang sudah diprediksi. kelompok jihadis seperti al-Qaeda merupakan bentuk paling radikal dari Islamisme kontemporer, sementara Islamisme nasionalis diwakili oleh kelompok Ikhwanul Muslimin. Kelompok yang kedua ini, termasuk juga kelompok fundamentalisme non-jihad, dapat dianggap kurang radikal karena arus ini meniadakan kaum abolisionis yang pada umumnya bertujuan untuk mewujudkan integrasi politik, atau menolak kekerasan teroris. Komunike dan pernyataan publik al-Qaeda memberi 
wawasan tentang wacana dalam gerakan Islam. Artikel ini akan membandingkan posisi politik al-Qaeda dengan gerakan dan organisasi Islam lainnya.

Ketiga, artikel yang ditulis oleh Khalil Al Anani dan Mazlee Malik bertajuk "Pious Way to Politics: the Rise of Political Salafism in Post Mubarak Egypt." Artikel ini membahas kebangkitan Salafisme setelah Mubarak dan memeriksa pengaruhnya terhadap transisi demokrasi di Mesir. Dalam penelitian ini, Al Anani dan Malik menyelidiki sikap ideologis dan teologis gerakan Salafi dan partai-partai politik khususnya tentang demokrasi. Argumen yang diajukannya adalah bahwa keterbukaan politik yang luar biasa di Mesir setelah revolusi telah mendorong kelompok Salafi ke dalam politik sehari-hari. Selanjutnya, kelompok Salafi menjadi lebih cenderung untuk mengadopsi wacana pragmatis dan praktis. Berdasarkan penelitian lapangan, artikel ini memberikan analisis tematik Salafisme Mesir dan menilai masa depan politiknya.

Keempat, artikel lain yang juga membahas tentang gerakan Salafi di Mesir adalah tulisan Jacob Hoigilt dan Frida Nome berjudul "Egyptian Salafism in Revolution." Pertanyaan utama yang diangkat dalam artikel ini adalah bagaimana politisasi Salafisme mengubah gerakan Salafi. Untuk menjawab pertanyaan ini, Hoigilt dan Nome menyajikan pemahaman akademis tentang Salafisme yang mapan, yang dilanjutkan dengan tinjauan singkat tentang evolusi Salafisme sebagai gerakan sosial. Mereka kemudian memetakan lanskap politik Salafi saat ini dan hubungannya dengan aktor lain dan membandingkan temuan kami. Berdasarkan pernyataan dan praktik Salafi sejak revolusi Mesir, mereka melihat bahwa gerakan Salafi telah menunjukkan kemampuan beradaptasi yang luar biasa terhadap keadaan politik yang berubah di Mesir. Fleksibilitas ini menantang pandangan Salafisme yang diterima sebagai arus religius yang berpusat pada teologi yang kaku.

Kelima, tulisan Mark Woodward berjudul "The Islamic Defenders Front: Demonization, Violence and the State in Indonesia." Dalam tulisan ini, Woodward mengeksplorasi cara Front Pembela Islam (FPI) menggunakan pidato kebencian dan demonisasi untuk melegitimasi serangan kekerasan terhadap organisasi dan individu yang dianggap berdosa atau menyimpang. Melalui artikel ini, Woodward berpendapat 
bahwa penggunaan bingkai diskursif melalui fatwa yang dikeluarkan oleh Majelis Ulama Indonesia Majelis Ulama Indonesia (MUI) dan dukungan secara diam-diam dari faksi politik yang kuat memungkinkan FPI melakukan kampanye demonisasi dan kekerasan. Di sisi lain, hal ini juga menjadikan FPI seakan kebal terhadap hukum dan mampu menghindarkan mereka dari tuduhan sebagai organisasi teroris. Artikel ini juga menyebutkan bahwa FPI tidak hanya memiliki dua, namun tiga wajah, yakni sebagai (1) kelompok masyarakat sipil; (2) kelompok yang tidak manusiawi dan sering menjelekkan musuh; dan (3) secara eksplisit sebagai kelompok yang sering memanggil anggota dan pendukungnya untuk menyerang musuh. Dalam artikel ini Woodward juga mengurai gambaran tentang Salafisme yang menggunakan kekerasan.

Keenam, tulisan Ali Amin berjudul, "Deradikalisasi Berbasis Pesantren: Kasus Ar-Royyan Bogor.” Artikel ini merupakan hasil penelitian Amin dengan menggunakan pendekatan kualitatif melalui observasi, wawancara dan dokumentasi. Amin menjelaskan bahwa sementara ini ada asumsi yang menilai pesantren sebagai pusat pendidikan pelaku tindakan radikal. Padahal, menurut Amin, pesantren pada kenyataannya turut berkontribusi dalam melakukan upaya deradikalisasi. Kultur pendidikan pesantren yang membentuk karakter manusia menjadi lebih baik dan menghormati kepentingan orang lain, menampilkan jalan terang menuju insan kamil. Sehingga, untuk memahami deradikalisasi, perlu adanya pemahaman tentang hakikat radikalisasi itu sendiri, mengingat radikalisasi di Indonesia erat kaitannya dengan marginalisasi politik Islam di masa silam.

Ketujuh, tulisan Husnul Qodim di Jurnal Afkar Edisi Nomor 21 tabun 2007 berjudul "Dinamika Salafisme di Indonesia: Akar-Akar Intelektualitas dan Orientasi Ideologis yang Beragam." Tulisan ini membahas bagaimana gerakan fundamentalisme radikal diasumsikan berasal dari teologi non-toleran Salafisme. Padahal kenyataannya konsep Salafisme bukanlah entitas tunggal dan monolitik. Salafisme disebut sebagai yang tertuduh sehingga dalam artikel ini Qodim mencoba melakukan penelusuran terhadap akar-akar intelektualitas Salafisme khususnya di Indonesia. 
Kedelapan, buku yang ditulis oleh Roel Meijer pada tahun 2014 dengan judul Global Salafism: Islam's New Religious Movement. Buku ini berisi tentang doktrin-doktrin Salafisme, relasi Salafi dengan politik, perjuangan jihad Salafi, diskursus tentang gerakan-gerakan Salafisme, serta perjuangan Salafisme tentang identitas mereka di hampir seluruh dunia.

Penelitian yang kesembilan merupakan buku yang diedit oleh Din Wahid dan Jamhari Makruf berjudul "Suara Salafisme: Radio Dakwah di Indonesia" yang merupakan karya terbaru tentang Salafisme di Indonesia. Buku yang merupakan bunga rampai ini menjelaskan khusus bagaimana media radio digunakan sebagai corong dakwah Salafisme di banyak daerah. Sebagai sebuah kumpulan tulisan, maka tentu perspektif yang digunakan oleh para penulis sangat berbeda-beda dan dipengaruhi oleh latar belakang masing-masing penulis. Namun, secara keseluruhan bisa memberikan gambaran tentang perkembangan Salafisme di seluruh Indonesia dan penyebaran ide dan gagasan dakwah mereka melalui radio.

Berdasarkan pengamatan dan penelusuran terhadap sumbersumber tersebut, terlihat bahwa belum ada satu pun karya akademik yang mengkhususkan pembahasan pada aspek pola gerakan yang disandingkan dengan deradikalisasi Islam di Indonesia. Melalui penelitian ini penulis berharap akan muncul sebuah ciri khas gerakan Salafi di Indonesia dan ditemukan pola khusus dan model tersendiri Salafi Indonesia yang bisa jadi sangat berbeda dengan global salafism. Sehingga, peluang untuk melakukan kajian dan diseminasi gagasan masih sangat terbuka dan layak untuk dilanjutkan.

\section{Salafisme sebagai Gerakan Sosial}

Dalam membedah gerakan Salafi, peneliti menggunakan kerangka konsep yang merujuk pada pandangan James Wood ${ }^{12}$ yang menyatakan bahwa gerakan Salafi bisa dikategorikan sebagai gerakan sosial (social movement) karena memiliki sebuah ideologi yang dikembangkan dalam wadah tertentu, dengan melakukan sebuah transformasi nilai kepada orang lain. Pandangan Herbert Blummer digunakan untuk melihat perkembangan suatu gerakan. Blummer menyatakan bahwa setiap gerakan

12 James Wood, Social Movement (McGraw Hill Book Company, 1977), 45 
memiliki empat tahapan: tahap kekacauan sosial, tahap kegembiraan populer, formalisasi, dan institusionalisasi (pelembagaan). ${ }^{13}$ Blummer kemudian mengembangkannya dengan melihat lima aspek penting dalam setiap gerakan, yakni agitasi, pengembangan esprit de corps, pengembangan moral gerakan, pembentukan ideologi, dan pengembangan taktik operasi. $^{14}$

Dalam menyebarkan dakwahnya, gerakan Salafi bisa dikategorikan sebagai gerakan yang selektif terhadap kultur masyarakat dan memiliki orientasi high politics dengan penekanan pada etika-moral yang merujuk pada landasan utama Islam, Alquran dan Sunah. Dalam perspektif politik, proses mempengaruhi dan melakukan kontrol terhadap sumber kekuasaan dan otoritas melibatkan kompetisi dan bahkan konflik. ${ }^{15}$ Gerakan Salafi menentukan jalur persuasif guna menginginkan tatanan yang Islami tanpa mengambil jalur politik formal.

Kaum Salafi, kalau dilihat orientasi tindakannya yang merujuk pada konsep Weber, bisa dikategorikan sebagai kelompok yang berorientasi nilai yang bersifat absolut. Artinya, tindakan sosial dilakukan untuk merefleksikan dan mengaplikasikan nilai yang dianggap absolut. ${ }^{16}$ Dengan kata lain, tindakan sosial itu sebagai wujud kesadaran untuk menerapkan nilai guna mencapai kesuksesan atau kebahagiaan hidup. ${ }^{17}$ Tindakan yang dilakukan oleh kaum Salafi merupakan refleksi atas nilai-nilai Islam yang dipercaya bisa mendatangkan kebahagiaan dan kesuksesan. Nilai-nilai itu merupakan bagian dari nilai-nilai kehidupan yang harus dijalankan oleh umat Islam.

13 Herbert Blummer, "Social Movement" dalam Alfred MCClung Lee, (ed.), Principles of sociology (New York: Barnes and Nobles, Inc. 1966), 202.

${ }^{14}$ Ibid., 204.

${ }^{15}$ George A. Theodorson and Achilles G. Theodorson, A Modern Dictionary of Sociology (New York: Barnes and Noble Books, 1979), 303.

16 Graham Charles Kinloch, Sociological Theory, Its Development and Major Paradigms (McGraw Hill Book Company, 1977), 139.

${ }_{17}$ George Ritzer, Sociological Theory (USA: McGraw Hill Book Companies INC, 1996), 125. 


\section{Kompatibilitas dalam Deradikalisasi Islam}

Ketika muncul tuduhan bahwa kaum Salafi terkait dengan kelompok radikal dan pendukung aksi terorisme, beberapa narasumber seoerti dai dan tokoh kaum Salafi menyangkal hal tersebut. Mereka berargumen bahwa Salafisme adalah gerakan pemurnian Islam. Bagi mereka, penguatan terhadap tauhid bukan hanya menjadi penting tetapi harus menjadi prioritas utama dalam mengenalkan agama. Apa yang didakwahkan oleh gerakan Salafi semata-mata untuk menyampaikan ilmu dan mendidik agama. Meski demikian, gerakan tersebut seringkali dianggap menggangu kelompok lain, yang pada akhirnya mendapat respons dengan tindakan mendiskreditkan atau menyesatkan kelompokkelompok Salafi. Hal ini sebagaimana dipaparkan oleh Ali Musri:

Perlawanan terhadap celana cingkrang dan jenggot hanya karena kebodohan dan ketidaktahuan mereka. Namun mereka yang berilmu dan mengaji mereka justru menghormati wahabi, namun dengan syarat tidak ada provokator. Kita semestinya tidak perlu terpengaruh ketika mendengar cemoohan itu seperti cap radikal. Ketika ada di antara mereka yang meninggal maka kita harus hadir dengan membelikan air, menyalatkan hingga menguburkan mereka. Namun mereka suka menyerang wahabi di berbagai kesempatan, di kuburan sekalipun. Umumnya, mereka tidak menanamkan ilmu. ${ }^{21}$

Pandangan di atas merupakan representasi pandangan kaum Salafi tentang pentingnya menanamkan dan mempraktikkan ilmu. Mengenakan celana di atas mata kaki (cingkrang) dan berjenggot diyakini sebagai bentuk pengamalan terhadap perintah Nabi dalam mendidik umatnya: berpakaian dan berpenampilan fisik yang membedakan dengan agama lain. Membelikan air minum dan menyalati jenazah mereka merupakan hal-hal yang diperintahkan oleh agama, meskipun mendapatkan banyak cemooh atau label sebagai kelompok radikal. Hal tersebut tidak menghalangi mereka untuk tetap berbuat baik kepada sesama Muslim.

Orientasi dan fokus terhadap dakwah ini benar-benar harus dilakukan oleh para dai. Hiruk pikuk politik hendaknya tidak melalaikan

\footnotetext{
${ }^{21}$ Wawancara, Ali Musri, Jember, 20 Agustus 2018.
} 
untuk terus berdakwah. Dengan memfokuskan diri pada kegiatan dakwah, maka masyarakaat benar-benar akan tercerahkan. Hal ini bisa dilihat dari pandangan Ali Musri sebagai berikut:

Dai tidak usah ribut dengan politik tetapi fokus dan sibuk berdakwah. Politik tidak menentu dan banyak mudharatnya bila energi habis untuk politik. PKS yang memiliki basis agama, tetapi bisa berkoalisi dan bersatu dengan PDI-P di Jawa Timur. Dakwah salaf tidak terombang-ambing karena politik. Kalau orang akidahnya benar maka akan memilih pemimpin yang terbaik. Kenyataan sekarang bahwa orientasi pemimpin dalam merebut kekuasaan bukan untuk kepentingan bangsa tetapi untuk kelompoknya sendiri dan memperkaya diri. Kita sering bergantung pada kekuatan diri kita dan melupakan kekuatan Allah. maka harus mendidik masyarakat dengan agama yang benar sehingga hati mereka bergantung pada Allah. ${ }^{22}$

Orientasi untuk terlibat secara aktif dalam bidang dakwah dan tidak terpengaruh oleh hiruk pikuk politik terlihat jelas dalam gerakan Salafi. Kegiatan dakwah memfokuskan pada tujuan untuk mendidik kaum muslimin sehingga perilaku masyarakat bisa lebih baik. Kepentingan politik bisa menjadi akar kerusakan dan adanya disorientasi bagi gerakan dakwah.

Adapun stigma radikal dan sesat yang dilekatkan pada gerakan Salafi tidaklah sepenuhnya benar. Hal itu sebagaimana disampaikan oleh Fadlan Pahamsyah bahwa stigma radikal yang disematkan pada kaum Salafi kurang tepat.

Salafiyun tidak setuju dengan istilah-istilah yang disematkan mereka bahwa kita adalah kaum radikalis atau minimal dianggap menumbuhkan bibitbibit radikal. Kalau dikatakan bahwa kaum Salafi merupakan gerakan merongrong Pemerintah atau mengadakan gerakan-gerakan separatis dan gerakan-gerakan anarkis, jelas ini tidak benar. Bahkan Salafi berbeda dengan gerakan transnasional lainnya yang mudah menjustifikasi kafir kepada Pemerintah. Kalau Salafi tidak, Salafi mengakui bahwa Presiden Indonesia adalah Wali Amri yang harus ditaati dalam kebaikan. Makanya dapat dicek datanya bahwa Salafi pernah demo di Indonesia ? Jadi kita

${ }^{22}$ Ibid. 
tidak sependapat dengan sematan itu dan di antara buktinya banyak, bisa di cek datanya, banyak pesantren-pesantren yang bersama-sama TNI Polri, termasuk juga pernah membuat acara besar tentang deradikalisme yang mengundang pihak kepolisian, pihak tentara bahkan kita juga ada workshop (pencerahan) dari kodim apa korem untuk mahasiswa. Jadi kita siap untuk mendukung Pemerintah dalam menangani aksi-aksi yang makar dan seterusnya itu. ${ }^{23}$

Pandangan ini menguatkan bahwa dakwah Salafi bukan dakwah radikal sebagaimana anggapan sebagian kaum muslimin. Sikap mudah melakukan pengkafiran tidaklah tepat disematkan kepada kaum Salafi. Buktinya, kelompok ini tidak pernah dianggap sebagai ancaman bagi pemerintah. Bahkan, bersama pemerintah mereka membantu upaya untuk melawan kelompok radikal.

Tuduhan bahwa kaum Salafi disebut kelompok yang mudah mengkafirkan kelompok lain adalah salah alamat. Hal itu dianggap sebagai parsialisasi pemahaman, sebagaimana dikatakan dai dan tokoh Salafi, Arifin Badri.

Dalam konteks dakwah (amar makruf nahi mungkar), merubah kemungkaran dengan kekuasaan itu bagi yang punya kekuasaan, adapun yang tidak punya kekuasaan dia tidak boleh mengubahnya dengan tangan dan hanya bisa mengubahnya dengan lisan, menasihati konteksnya. Sederhananya, suami dan istri itu kekuasaan suami atas istri. Apabila si istri membuka aurat, suami berhak dengan tangan (memukul, memberikan hukuman fisik) berdasarkan alasan yang dibenarkan selama dia tidak membuat cacat. Artinya, proporsional dalam rangka edukasi. Tetapi saya sebagai tetangganya bolehkah saya memukul dia ? jelas tidak boleh. Seperti yang saya katakan, masalah itu muncul ketika agama diterapkan secara tidak proporsional, ada parsialisasi pemahaman dan penerapan agama. Pasti akan terjadi ketimpangan salah satunya adalah radikalisme. Itu adalah parsialisasi pemahaman dan penerapan agama. ${ }^{24}$

Di sini jelas bahwa secara umum tuduhan sesat terhadap kaum Salafi yang dianggap sering menyesatkan kepada orang yang berbuat bidah,

\footnotetext{
${ }^{23}$ Wawancara dengan Fadlan Pahamsyah, Surabaya, 26 September 2018.

${ }^{24}$ Wawancara dengan Arifin Badri, Jember, 20 Agustus 2018.
} 
merupakan kesalahan besar. Kaum Salafi tidak pernah menuduh orang lain kafir secara personal tetapi hanya secara umum bahwa pelaku bidah akan masuk neraka sebagaimana yang dikatakan Nabi.

Sementara terkait dengan persoalan kepemimpinan, Pancasila, dan NKRI, kaum Salafi memiliki pandangan yang khas. Kaum Salafi berpandangan bahwa model kepemimpinan itu tidak baku, sangat bebas dan tidak terikat dengan label tertentu. Yang terpenting bagi mereka adalah pemerintahan itu memberi kontribusi dan memperjuangkan tegaknya nilai-nilai Islam. Hal ini disampaikan oleh Ali Musri sebagai berikut.

Islam tidak menentukan model pemerintahan secara khusus. Pemerintahan khilafah sebagaimana dikatakan Nabi berlangsung 30 tahun. Kemudian berubah menjadi kerajaan. Penamaan tidak penting, entah presiden, tuan guru, kiai, raja, atau apa itu terserah. Yang penting adalah menjalankan misi agama. Pancasila terlihat nilai-nilai Islam di dalam silasilanya. Bahkan Sila ke 4 sangat Islam banget. Sudah menjadi kenyataan bahwa semakin dekat sistem itu dengan Islam maka jaminan keamanan semakin dekat. Sebaliknya semakin jauh sebuah sistem negara dari Islam, maka semakin jauh dari keamanan. Kerajaan dalam Islam banyak kegemilangan yang diperoleh sehingga para ulama membiarkan hidup sistem ini dan tidak mempermasalahkan. ${ }^{25}$

Kaum Salafi berpandangan bahwa penamaan sistem bernegara tidaklah penting. Presiden, raja, sultan atau yang lainnya tidak penting selama hal tersebut membawa misi untuk memberi ruang bagi tegaknya agama. Nabi sudah memprediksi bahwa dalam bernegara akan terjadi masa khilafah (sebagaimana kbulafā al-rāshidūn), kemudian berganti menjadi kerajaan yang agung, dan kemudian bergeser lagi menjadi kerajaan yang zalim.

Adapun Pancasila, menurut mereka merupakan sistem bernegara yang sangat dekat dengan Islam. Hal ini dibuktikan dengan sila-sila yang terdapat di dalam Pancasila, seperti sila pertama "Ketuhanan Yang Maha Esa" yang merupakan wujud dari nilai-nilai tauhid yang mengakui bahwa Allah adalah Tuhan yang satu. Sementara sila keempat sangat jelas kandungan Islamnya di mana kata-kata "permusyawaratan", "hikmat",

${ }^{25}$ Wawancara dengan Ali Musri, Jember, 20 Agustus 2018. 
"kebijaksanaan", "rakyat”, dan "perwakilan” merupakan kata-kata yang mengandung nilai-nilai Islam yang agung. Jadi, Pancasila adalah bagian dari Islam yang tidak perlu dipertentangkan.

Berkaitan dengan demokrasi, kaum Salafi memiliki pandangan yang berbeda dengan kelompok Islam yang lain. Kaum Salafi berpandangan bahwa sistem demokrasi itu menuhankan suara sehingga menjadi problem besar bagi umat Islam. Hal ini dikatakan oleh Ali Musri sebagai berikut:

Demokrasi adalah sebuah proses untuk memilih pemimpin. Demokrasi menuhankan suara karena mendasarkan pada jumlah suara. Hukum asal demokrasi adalah mempertuhankan suara dengan mengambil suara terbanyak. Dalam pandangan Islam, mendasarkan pada suara sangat tidak adil karena menyamakan suara satu orang dengan orang yang lain. Tukang becak sama dengan suara ulama. Dalam demokrasi, materi yang bisa didiskusikan adalah perkara-perkara yang halal, mubah, makruh. Bukan membahas hal-hal yang haram. Dalam demokrasi semuanya sama dan bisa diwacanakan untuk diperbolehkan, termasuk masalah LGBT, pelacuran, dan minuman keras. Kalau pun yang dibicarakan tentang LGBT, pelacuran, dan minuman keras menyangkut cara penanganannya agar tidak terjadi dan menyebar. ${ }^{26}$

Pandangan di atas menunjukkan bahwa kaum Salafi menilai demokrasi sebagai sistem yang "menuhankan" suara. Hal itu dipandang tidak adil karena menyamakan suara ulama dengan orang awam yang tidak memiliki wawasan agama. Mereka berpendapat bahwa seharusnya kebenaranlah yang menjadi tolok ukur, bukan banyaknya suara. Ketika demokrasi mengutamakan jumlah suara terbanyak, hal tersebut memungkinkan kebenaran bisa tersisihkan dan dikalahkan hanya dengan suara yang menolaknya.

Hal ini berimplikasi pada persoalan haram yang bisa digeser dan berganti menjadi halal ketika banyak suara yang menghendaki perubahan hukum itu. Bahkan dalam mendiskusikan suatu kebijakan, suara terbanyak menjadi bahan pertimbangan sehingga bisa menghalalkan hal yang haram, seperti peredaran minuman keras di tengah masyarakat atau bisnis prostitusi. Dalam Islam, sesuatu yang jelas keharamannya sudah tidak

${ }^{26}$ Ibid. 
perlu didiskusikan lagi dan hal yang haram tidak bisa diubah hukumnya menjadi halal. Perjudian, pelacuran dan peredaran minuman keras, atau LGBT jelas keharamannya, sehingga tidak bisa diubah menjadi halal karena banyaknya suara yang ingin menghalalkannya.

Kaum Salafi memandang demokrasi merupakan sistem bernegara yang berbeda dan bahkan bertentangan dengan Islam. Demokrasi merupakan fitnah bagi umat Islam, sehingga bisa terpilih pemimpin yang menyimpang dari nilai-nilai Islam.

\section{Perlawanan terhadap Salafi}

Fenomena perlawanan terhadap dakwah salaf bukan semata-mata soal benar salah, tetapi soal kontestasi atau perebutan pengikut. Kesadaran masyarakat untuk mencari agama yang benar telah mengusik kelompok yang telah mapan dan menguasai masyarakat. Hal ini dikatakan Ali Musri:

Perlawanan terhadap dakwah Salaf tidak lepas dari adanya fenomena kontestasi antara Salafi dan NU. Keduanya sudah memiliki pengaruh. Bedanya pengaruh kelompok salaf demikian cepat menggerus kelompok kedua. Orang Salafi sudah cerdas dan tidak terpengaruh dengan tradisi, sebaliknya pengikut NU yang banyak masuk dan bergeser masuk ke dalam dakwah salaf. Masuknya orang NU ke politik tidak lepas dari upaya untuk memperkuat posisi mereka yang saat ini kendor. Mereka meneriakkan moderasi tetapi sulit untuk mempraktikkannya. Mereka menguasai 90 persen masjidmasjid pemerintah (masjid agung) dan berkuasa penuh. Tapi kenapa tidak ada pembagian jadwal dakwah dengan memberikan kesempatan pada Muhammadiyah. Mana Moderasinya? Apalagi Salafi, pasti tidak diberi tempat. Mereka ngomong toleransi padahal masjid itu milik publik bukan milik NU. Minimal mereka berbagi dengan memberi ruang kepada Muhammadiyah sekali dalam tiga bulan untuk berdakwah. Mereka justru menghadang yang mendirikan sekolah yang dianggap akan melawan tradisi mereka. Di UIN atau Kementerian Agama juga dihabisi dan tidak ada toleransi. Toleransi dan keberagaman adalah dengan non Muslim, bukan untuk sesama Muslim. ${ }^{27}$

27 Ibid. 
NU merupakan ormas Islam yang tidak ingin tradisi mereka hilang. Ketika melihat dakwah salaf, mereka melakukan perlawanan. Seandainya mereka mau merujuk pada landasan Islam yang benar, maka akan banyak kesamaan antara keduanya. Namun, faktanya, ketika mereka melihat dakwah kelompok Salafi, mereka ingin menyelisihi karena bertentangan dengan tradisi mereka yang amat lemah. Membuat gagasan Islam Nusantara hanyalah sebuah upaya yang ingin menjadi berbeda dari arus utama masyarakat yang sudah memiliki kesadaran beragama.

Konflik kaum Salafi dengan NU lebih banyak bernuansa perebutan pengaruh. Gencarnya dakwah salaf benar-benar membuka kesadaran kaum muslimin untuk mengenal agamanya. Ketika kaum muslimin mengenal agamanya dengan benar, maka tradisi yang selama ini dikembangan NU menjadi berkurang. Sehingga, jumlah kaum muslimin yang melakukan praktik ritual bidah yang selama ini sudah menjadi hal yang biasa pun turut berkurang. Maulidan (perayaan memperingati kelahiran Nabi Muhammad saw.), slametan kematian, atau haul sudah mulai ditinggalkan. Di sinilah konflik berawal dan pada perkembangannya memunculkan aksi pembubaran atau pengusiran terhadap aktivitas dakwah kelompok Salafi.

Keterancaman NU bisa dilihat dari perilaku non-moderasi dengan membubarkan kajian yang diselenggarakan kelompok Salafi atau melakukan demonstrasi sebagai reaksi atas pendirian sekolah oleh kelompok Salafi. Bahkan, perilaku non-moderat itu bisa dilihat ketika kaum Nahdhiyyin menguasai sebagian besar masjid pemerintah tanpa memberi kesempatan kepada kelompok lain untuk berbagi. Bahkan di berbagai kesempatan, NU selalu melakukan sosialisasi adanya bahaya wahabi.

\section{Penutup}

Paham keagamaan Salafi di Indonesia tidak berbeda dengan gerakan keagamaan yang lain, dimana mereka mengusung dan memperjuangkan tegaknya nilai-nilai keislaman. Hal yang membedakan kaum Salafi dengan gerakan lain adalah bagaimana mereka memahami agama, fokus, dan strategi dakwahnya. Pemahaman agama kaum Salafi merujuk pada pemahaman Islam tiga generasi terbaik Islam, yakni para 
sabahat, tabiin, dan tabiin-at-tabiin. Sementara fokus dakwahnya dengan menekankan pada ajaran tauhid. Adapun strategi yang dilakukan adalah mendidik kaum muslimin dengan ajaran agama yang telah mengalami taşfiyah dan tarbiyah. Artinya, kaum muslimin diajarkan dengan agama yang bersih dari berbagai anasir-anasir yang tidak bersumber dari Allah dan Rasul-Nya.

Pola gerakan Salafi di Indonesia demikian masif dengan melakukan kajian, dan pendirian lembaga-lembaga pendidikan dan pesantren. Berkembang pesatnya dakwah kaum Salafi tidak lepas dari tumbuh menjamurnya kajian-kajian secara intensif yang merambah di perkotaan maupun pedesaan. Kajian-kajian yang demikian intensif itu semakin berkembang secara masif ditopang oleh media sosial, baik radio, televisi, Facebook, What's Apps, maupun majalah atau buletin.

Kajian-kajian yang intensif itu benar-benar menumbuhkan spirit beragama yang kemudian mendorong mereka untuk membentuk komunitas-komunitas dan akhirnya mendirikan lembaga pendidikan dan pesantren. Tumbuh berkembangnya lembaga pendidikan dan pesantren itu mulai dari tingkat dasar, menengah hingga perguruan tinggi. Perkembangan dakwah kaum Salafi yang demikian pesat inilah yang kemudian memperoleh respons negatif dari kelompok masyarakat yang merasa tersaingi atau terancam eksistensinya. Penekanan pada tauhid dan menolak budaya agama yang tercampuri oleh budaya lokal, yang bertentangan dengan Islam, membuat dakwah kaum Salafi ini mendapatkan tantangan dari mereka yang merasa tersaingi. Tantangan itu, misalnya, mulai dari tuduhan, tekanan, ancaman, hingga pengusiran merupakan kenyataan yang sulit dihindari.

Adapun tuduhan sesat dan radikal, larangan untuk mengadakan kajian, demonstrasi untuk menghentikan dakwah hingga pengusiran dari tempat tinggal tidak menyurutkan langkah untuk terus berdakwah. Larangan membangun masjid atau lembaga pendidikan merupakan bagian yang tak terelakkan. Namun, hal ini tidak menyurutkan langkah mereka untuk terus bergerak menyebarkan dakwah tauhid.

Kompatibilitas paham keagamaan mereka dalam konteks deradikalisasi Islam di Indonesia bisa dilihat dari dua sisi. Pertama, kaum Salafi merupakan gerakan dakwah yang meneguhkan prinsip-prinsip 
beragama dengan menekankan pada tauhid. Penyematan sebagai kelompok radikal tidak bisa dipungkiri karena kaum Salafi memiliki kesamaan ekspresi beragama melalui penampilan fisik mereka dengan gerakan-gerakan Islam lainnya, seperti berjenggot, celana cingkrang. Namun, faktanya, gerakan dakwah Salafi ini juga dianggap sebagai "musuh" oleh kelompok takfin $\bar{\imath}$ yang menganggap gerakan Salafi sebagai gerakan yang lemah dalam menghadapi penguasa yang zalim.

Kedua, Pancasila merupakan ideologi negara yang tidak perlu dipertentangkan dengan Islam karena inti dari Pancasila banyak terinspirasi oleh nilai-nilai ajaran Islam. Dengan kata lain, Pancasila merupakan hasil karya dan pemikiran umat Islam. Penafsiran yang salah terhadap butir-butir Pancasila, sebagaimana yang ditafsirkan oleh kelompok liberal dan sekuler, berpotensi besar untuk memunculkan penyimpangan terhadap nilai-nilai Islam.

Ketiga, demokrasi merupakan fitnah bagi umat Islam. Dalam pandangan kaum Salafi, demokrasi merupakan sistem politik yang bersumber dari orang Barat dan kafir. Sementara Islam sendiri memiliki konsep tersendiri dalam memilih pemimpin, yang disebut dengan istilah shu'arā. Dalam konsep ini, hanya orang-orang tertentu dengan kapasitas dan kemampuan, baik dalam hal agama maupun pemerintahan, yang dilibatkan dalam proses pemilihan pemimpin. Sementara demokrasi melibatkan seluruh unsur masyarakat.

Dalam pandangan pandangan kaum Salafi, demokrasi demikian "menuhankan" jumlah suara sehingga satu suara ulama disetarakan dengan satu suara orang awam yang tidak mengerti agama. Oleh karena itu, kaum Salafi tidak terlalu memfokuskan diri pada Pemilu yang merupakan bagian dari proses demokrasi. Meskipun tidak mengikuti proses Pemilu, kaum Salafi tetap mengakui hasil pemilihan pemimpin dengan mengakui kepemimpinannya. Inilah yang membedakan kaum Salafi dengan gerakan Islam lainnya dalam merespons demokrasi. Meskipun seandainya mereka mengikut proses Pemilu dengan memilih figur seorang pemimpin, bagi mereka hal yang demikian bukan berarti mereka mengikuti proses berdemokrasi tetapi semata-mata memotivasi untuk merespons keadaan. Artinya, keadaan harus memilih satu di antara dua pemimpin yang dipandang mampu membawa kemaslahatan bagi umat Islam. 
Pertumbuhan gerakan dakwah Salafi yang semakin pesat, mulai dari perkotaan hingga pelosok pedesaan, telah menimbulkan gesekan. Pertumbuhan ini dianggap bisa mengganggu eksistensi kelompok yang selama ini mapan. Oleh karena itu, diperlukan kedewasaan dari kedua belah pihak, dan pihak ketiga sebagai jembatan-dalam hal ini pemerintahuntuk melakukan komunikasi guna meminimalisir terjadinya gesekan, menumbuhkan perasaan saling menghargai dan menghormati terhadap perbedaan yang ada.

Maraknya persekusi terhadap kelompok yang dianggap radikal dan sesat semakin memperuncing konflik di tengah masyarakat. Munculnya sebagian kelompok masyarakat yang membubarkan pengajian atau mengusir kelompok yang dianggap menyimpang seharusnya dapat dihindari. Oleh karena itu, diperlukan perangkat dan kepastian hukum, serta mendorong masyarakat untuk melaporkan pelaku tindakan yang meresahkan masyarakat kepada pihak yang berwajib. Perangkat hukum harus dipersiapkan guna mencegah dan menangani konflik berlatar belakang agama. Demikian pula, masyarakat perlu memiliki rasa percaya terhadap aparat penegak hukum dalam menangani kasus-kasus tersebut. Hal ini diperlukan dalam rangka menjaga stabilitas sosial di masyarakat dan mencegah kegaduhan yang kontraproduktif.

Oleh karena itu, penelitian ini mengharapkan terciptanya iklim bermasyarakat yang tidak mudah terprovokasi oleh klaim-klaim menyesatkan, sehingga melakukan tindakan-tindakan kontraproduktif atau mudah melakukan tindakan persekusi terhadap kelompok yang dianggap sesat dan radikal. Di sisi lain, pemerintah juga diharapkan menjadi hakim yang bersifat netral dengan menegakkan aturan yang berlaku dan memberikan tindakan dengan tegas terhadap pihak-pihak yang terbukti menciptakan keonaran dan kegaduhan di masyarakat. Lebih dari itu, tokoh agama dan pemuka masyarakat diharapkan turut pro-aktif dalam menghadapi berbagai kelompok yang dianggap menjadi pemicu persoalan di tengah komunitas masyarakat beragama. Mereka diharapkan mampu menjadi penengah dan pendengar yang baik ketika terjadi konflik antar kelompok agama, bukan justru ikut terprovokasi dan memihak pada salah satu kelompok. 


\section{Daftar Pustaka}

Adams, Ian. Ideologi Politk Mutakhir. Yogyakarta: 2004.

Al Anani, Khalil and Malik, Mazlee. "Pious Way to Politics: The Rise of Political Salafism in Post Mubarak Egypt." Digest of Middle East Studies Volume 22 Nomor 1 tabun 2013.

Al-Imam, Muhammad Bin Abdillah. Menggugat Demokrasi dan Pemilu. Banyumas: Pustaka Salafiyah, 2007.

Amborst, Andreas. "Radicalisation and De-Radicalisation of Social Movement: The Comeback of Political Islam?" Crime, Law and Social Change, 62(3), 235-255. doi:10.1007/s10611-013-9464-8.

Amin, Ali. "Deradikalisasi Berbasis Pesantren: Kasus Ar-Royyan Bogor." Jurnal Harmoni Volume 11 Nomor 3. 2012.

Armanios, Febe. "The Islamic Traditions of Wahhabism and Salafiyya." CRS-Report for Congress, December, 22. 2003.

Atsari, Abdullah bin Abdul Hamid. Intisari Aqidab Abl al-Sunnah wal Jama'ah. Jakarta: Pustaka Imam Asy-Syafi'i, 2007.

Azra, Azyumardi. Pergolakan Politik Islam: Dari Fundamantalisme, Modernisme, dalam Syariat Islam. Jakarta: Darul Falah, 2006.

Berman, Paul. Terror and Liberalism. New York: WW Norton, 2003.

Bruinessen, Van. "Genealogies of Islamic Radicalism in Post-Suharto Indonesia." South East Asia Research, 10, 2. 2000.

Effendi, Bahtiar. Islam dan Negara, Transformasi Pemikiran Politik Islam di Indonesia. Jakarta: Paramadina, 2003.

Egerton, Frazer. "Alienation and its Discontent." European Journal of International Relation, volume I7 Nomor 3, 2010.

Feith, Herbert dan Castles, Lance (ed.). Pemikiran Politik Indonesia 1945 1965. Jakarta: LP3ES, 1995.

Flew, Anthony. A Dictionary of Philosophy. New York: St. Martin's Press, 1984.

Giovani Sartori, Political Man: The Theory of Democracy Revisited. New Jersey: Chatam, 1987.

Kinloch, Graham Charles. Sociological Theory, Its development and Major Paradigms. New York: McGraw Hill Book Company, 1977.

Kurzman, Charles. Wacana Islam Liberal, Pemikiran Islam Kontemporer tentang Isu-isu Global. Jakarta: Paramadina, 2003.

Lee, Alfred MCClung (ed.). Principles of sociology. New York: Barnes and Nobles Inc., 1966.

Mannheim, Karl. Ideologi dan Utopia: Menyingkap Kaitan Pikiran dan Politik. Yogyakarta: Kanisius, 1991. 
Meijer, Roel. Global Salafism, Islam's New Religious Movement. London: Hurst and Company, 2009.

Moleong, Lexy. Metodologi Penelitian Kualitatif. Bandung: Remaja RosdaKarya, 2005.

Mubarok, Zaki. Genealogi Gerakan Radikal Islam Indonesia. Jakarta: LP3ES, 2003.

Mughni, Syafiq (ed.). An Anthology of Contemporary Middle Eastern History. Montreal: Canadian International Development Agency.

Newman, Isadore and Benz, Carolyn R. Quantitative-Qualitative Research Methodology, Exploring the Interactive Continum. USA: Southern Illinois University Press, 1998.

Qodim, Husnul. "Dinamika Salafisme di Indonesia: Akar-Akar Intelektualitas dan Orientasi Ideologis yang Beragam," Jurnal Afkear Edisi Nomor 21 tabun 2007.

Ramadhani, Abdul Malik bin Ahmad. Enam Pilar Dakwah Salafiyah. Jakarta: Pustaka Imam Asy-Syafii, 2004.

Sihbudi, Riza. Gerakan Islam Radikal Di Indonesia. Jakarta: LIPI, 2004.

Taimiyah, Ibnu. Siyasah Syar'iyyah. Surabaya: Risalah Gusti, 2005.

Theodorson, George A. and Theodorson, Achilles G. A Modern Dictionary of Sociology. New York: Barnes and Noble Books, 1979.

Wahid, Din dan Makruf, Jamhari. Suara Salafisme: Radio Dakwah di Indonesia. Jakarta: PPIM-PrenadaMedia Group, 2017.

Wictorowicz, Quintan. "A Genealogy of Radical Islam," Studies in Conflict and Terrorism, Vol. 28, 2005.

. "The New Global Threat: Transnasional Salafis and Jihad." United States of America Middle East Policy, Vol. VIII, No 4, December. 2001.

. "The Salafi Movement in Jordan." International Journal of Middle East Studies, 32. 2000.

Wood, James. Social Movement. New York: McGraw Hill Book Company, 1977.

Woodward, Mark. "The Islamic Defenders Front: Demonization, Violence and the State in Indonesia," Springer, 28 December 2013. 